УДК 2-28.09

https://doi.org/10.18485/msc50.2019.1.ch24

Кетрин Мекроберт

\title{
КАКАВ ЈЕ БИО ПСАЛТИР СРПСКИХ СРЕДҢОВЕКОВНИХ КњИЖЕВНИКА?
}

Сви они које интересује проучавање утицаја Светог писма и начин коришћења цитата из Светог писма у српској средњовековној књижевности уживају велику предност због тога што могу да користе одличну студију коју су саставили Станојевић и Глумац и издали 1932. године. ${ }^{1}$ Циљ аутора био је да пруже помоћ у идентификацији библијских цитата и да осветле начине, на које су средњовековни писци користили Библију: из којих су књига најрадије цитирали, и да ли су цитате наводили тачно, или по сећању, или су вршили свесне измене. Станојевић и Глумац су имали, такође, на уму да би материјал који су они сакупили могао да буде од користи и онима које занима текстуална традиција црквенословенских превода Светог писма. Из тог разлога, колико је то било могуће, покушавали су да укажу на изворе који би објаснили варијације у библијским цитатима. Од 1932. године на овамо, међутим, напредовало се у историјском проучавању различитих редакција Светог писма, које су биле у оптицају међу Словенима у средњем веку. Овај реферат комбинује та открића са материјалом Станојевића и Глумца у покушају да разјасни које су верзије Псалтира биле знане средњовековним српским писцима.

Анализа било ког средњовековног текста који је до нас допро у преписима, а не у оригиналу, мора увек да узме у обзир могућност каснијих писарских измена. То важи за библијске цитате, колико и за било који други део текста, ако не и више: писари су често вршили измене у препознатљивим фразама или стиховима из добро знаних делова Библије као што је то Псалтир, да би их прилагодили стандардној верзији свога времена. Као што Станојевић и Глумац показују, овај процес је очигледан у три рукописа дела архиепископа Данила II и његових настављача.

${ }^{1}$ Ст. Станојевић и Д. Глумац, Св. Писмо у нашим старим споменииима, Београд, 1932. 
Старији карловачки рукопис (Кa), који је Даничић користио као основу за своје издање ${ }^{2}$, обично цитира Псалтир према ранијим редакцијама, док каснији карловачки рукопис (Кб) осавремењује формулацију ових цитата. На пример у псалму 75:12 Ка нуди ов 'штантє єє из прве редакције (коју овде представљају првенствено Синајски глагољски ${ }^{3}$, Погодинов и Болоњски псалтир $\left.{ }^{4}\right)$, док Кб има помолнтє сє. Ова реч је ушла у традицију у другој редакцији (коју овде представљају руски рукописи Синајски 6 из XI века ${ }^{5}$, Харвардски из XII века ${ }^{6}$, Јарославски из XIV века7 и српски рукописи са краја XIII века, Пљеваљски псалтир и Београдски одломци ${ }^{8}$ ). Она се проширила у касније рукописе прве редакције, на пример Дечански псалтир ${ }^{9}$ и Синајски $8^{10}$, а јавља се редовно у новим редакцијама из XIV века. Tрећа, односно светогорска ${ }^{11}$ редакција, заступљена је у Томичевом ${ }^{12}$, Карадимовљевом и Минхенском ${ }^{13}$ псалтиру и у рукопису 34 из универзитетске библиотеке у Београду. Четврта редакција посведочена је у руским изворима из XV века ${ }^{14}$, на пример Кипријанов псалтир и Би-

2 ед. Ђ. Даничић, Архиепископ Данило и други, Животи кральва и архиепископа српских, Загреб, 1866 / Лондон, 1972.

3 С. Северјанов, Синајскаја псалтир'. Глаголическиј памјатник XI века, Петроград, 1922; M. Altbauer, Psalterium sinaiticum. An 11th century Glagolitic Manuscript from St. Catherine's Monastery, Mt. Sinai, Skopje, 1971; I. C. Tarnanides, The Slavonic Manuscripts Discovered in 1975 at St. Catherine's Monastery on Mount Sinai, Thessaloniki, 1988.

4 В. Јагић, Словенскаја псалтир'. Psalterium bolloniense, Vienna-Berlin-St. Petersburg, 1907; И. Дујчев, Болонски псалтир, Софиа, 1968.

5 M. Altbauer, and H. G. Lunt, An Early Slavonic Psalter from Rus', Cambridge, Mass., 1978.

6 Ibid.

7 C. M. MacRobert, Two Lykewake Psalters: The MSS Västeras/UUB5/UUB6 and Jaroslavl' 15482, Scando-Slavica 38 (1992), 108-27.

${ }^{8}$ C. M. MacRobert, The Systems of Supplementary Penitential Texts in the Psalter MSS Peć 68, Belgrade 36, and Pljevlja 80, Oxford Slavonic Papers NS 24 (1991) 1-22.

9 ф. 182, MC 17 у Руској Народној Библиотеци у Санкт-Петербургу.

10 M. Atlbauer, Der älteste serbische Psalter, Cologne-Vienna, 1979.

11 Е. В. Чешко, Ob afonskoj redakcii slavjanskogo perevoda psaltyri y ee otnošenii $k$ drugim redakcijam, Jazyk i pis'mennost' srednebolgarskogo perioda edd. E. V. Češko, E. I. Demin et al., Москва, 1982, 60-93.

12 А. Џурова, Томичов псалтир 1-2, Софиа, 1990.

13 S. Dufrenne, Sv. Radojičić, R. Stichel and I. Ševčenko, Der serbische Psalter 1-2, Wiesbaden, 1978-83.

14 Е. В. Чешко, Второе јужнославјанское влијание в редакиии псалтирного текста на Руси XIV-XV вв., Palaeobulgarica 5:4 (1981) 79-85. 
блија архиепископа Генадија ${ }^{15}$, али је сигурно јужнословенског порекла из XIV века. Изоловану редакцију представља Норовљев псалтир ${ }^{16}$, такође из XIV века.

Ситуација је слична и у другим цитатима из Ка и Кб. Ка следи прву и другу редакцију, а у случајевима где се слаже с каснијим верзијама, на пример у псалму 15:3 или 75:10, ради се о очувању формулације из раних превода. Може се чак и видети у псалму 85:11 да је Данило користио прву редакцију, у којој налазимо ндвєдн, а не другу редакцију, која има направн. Међутим, оно што рукописи показују није сасвим једноставно: на једном месту у Житију Стефана Дечанског Ка цитира псалам 4:1 према првој и другој редакцији, али на самом почетку Житија иста алузија се јавља у формулацији за коју паралелу налазимо само у Норовљевом псалтиру. Може бити да је Данилов настављач овде у ствари консултовао примерак ове нове редакције, која мора да је већ постојала средином XIV века, у време када је он радио; међутим могућност касније писарске интервенције не може се искључити. Ова могућност постаје вероватнија ако се Ка пореди са трећим рукописом, који се налази у Лавову. На неколико места Лавовски рукопис (Л) чува читање, карактеристично за прву редакцију, док Ка следи неку каснију верзију, на пример сьвора из друге редакције у псалму 39:11, формулације из XIV века у псалму 83:12 и у поновљеном цитату из псалма 85:11, а модерни израз сєлєннга у псалму 83:1. Такве разлике наводе на помисао да је Л не само верније сведочанство од $K б$, већ да би и читања овог рукописа понекад требало сматрати ближим оригиналу него читања из Ka.

Не изненађује чињеница да Кб, писан рускословенским крајем XVIII века, одражава текстуалне традиције које су допринеле стварању рускословенског псалтира у Синодалној Библији. Што је занимљивије, Данило и његов настављач, пишући у првој половини XIV века, цитирају Псалтир, не према новим исправљеним редакцијама, које у то време улазе у употребу, него према старијим редакцијама које мора да су знали из младости. Насупрот томе, аутор додатка, касније у XIV веку, јасно користи нове редакције, на пример кад цитира псалам 54:9.

Уопштено говорећи чини се да су српски писари пратили текстуални развој црквенословенског псалтира. У повељама из XIV века, на пример, најранији случај цитирања из псалма 25:8, из 1318. године, у

${ }_{15}$ G. Freidhof, Auszüge aus derr Gennadius-Bibel (1499). Nr. 1: Der Psalter, Frankfurt am Main, 1974.

${ }^{16}$ Е. В. Чешко ет ал., Норовскаја псалтир: Среднеболгарскаја рукопис XIV века 1-2, Софиа, 1989. 
ствари садржи нови исправљени израз Благольпнє, док се ранији израз красоту први пут налази у повељи из 1330. године. Исте године, псалам 132:1 се још увек цитира према првој и другој редакцији, али се већ 1357. године јавља нова верзија. Овај процес обнове може се открити и у XIII веку: 1242. године цитат из псалма 101:27 садржи необичну формулацију, каква је карактеристична само за српске рукописе друге редакције (Пљеваљски и Београдски псалтир); али се већ 1288. године формулација истог цитата јавља као претеча исправљене верзије из треће и четврте редакције.

Чак и у записима које је сакупио Стојановић ${ }^{17}$, где се очекује да писари наводе по сећању па да према томе чувају стару верзију, средином XIV века се уочава промена у пракси: пре тога мали број цитата из Псалтира могао је да се односи на прву или другу редакцију, али затим преовлађују исправљене верзије XIV века. Штавише, цитирање је доста тачно: чак су и несрећни затвореници, који су саставили запис из 1360. године, погрешили само једном, написавши нє оүпованте на кнєZє, а не нє надЊнте сА на кнАДА у доста дугом цитату од 32 речи из псалма 145, који је вероватно навођен по сећању (осим ако им за утеху у затвору није даван Псалтир).

На тај начин, у идентификацији цитата из Псалтира које су наводили српски писци од средине XIV века надаље, треба консултовати нове верзије текста које су до тога времена ушле у стандардну употребу, а не тражити паралеле у изворима као што су Синајски, Погодинов и Болоњски псалтир, или пак такозвани 'најстарији' српски псалтир који је објавио Алтбауер. Али какав су Псалтир користили писци XIII века? На жалост тешко је одговорити на ово питање у случају св. Саве, јер он више користи Нови завет. Ипак његови малобројни цитати из Псалтира одговарају првој и другој редакцији. Његов брат Стефан Првовенчани као да више воли другу редакцију, на пример у псалмима 21:17 и 36:6, али специфични изрази овде нису много наглашени и можда једноставно одражавају општије лексичке тенденције у његовом избору речи из црквенословенског.

Доментијанови списи ${ }^{18}$ нуде шири и дефинитивнији доказни материјал. Истина, могло би се претпоставити, када се отвори Житије Св. Симеона, да је Доментијан већ знао или унапред погодио верзије Псалтира које налазимо у XIV веку, јер његов први цитат из псалма 31:1, чьто

17 Љ. Стојановић, Стари српски записи и натписи, 1-6, Београд, 1902-6 / 1982-8.

18 ed. Ђ. Даничић, Доментијан, Живот Светога Симеуна и Светога Саве, Београд, 1865. 
АоБро нин чьто Красьно єже жнтн Братнн вь коүпћ, одговара овим верзијама; али Доментијан се касније у тексту враћа формулацији из прве и друге редакције: сє коль довро н коль красьно єжє жнтн свєтныл вь коүпЊ. Можда је од значаја то што у овом случају он доноси приближан навод, прилагођавајући стих псалма контексту, тако што реч Братнн замењује речју свєтнща. По свему судећи цитирање по сећању је било вероватније онда, када је писац уткао библијску алузију у свој текст, него када је нудио експлицитни цитат.

Рана редакцијска повезаност Доментијанових цитата је очигледна на другим местима, али они не одражавају неопходно ону верзију прве редакције, са којом је модерна наука највише упозната. Неки наводи, на пример из псалама 39:3 и 46:9, следе другу редакцију, која се јавља у српским рукописима касног XIII века, Пљеваљском и Београдском псалтиру. За друге цитате, из псалама 54:23, 85:14, 46:8, 141:5, 131:4, налазимо паралеле у рукописима које овде узимамо за представнике прве редакције, али само у рукописима који садрже служабни Псалтир, наиме Григоровичев ${ }^{19}$, Дечански и Синајски 8 . У овим рукописима има знакова контаминације другом редакцијом. Понекад су редакције заиста у тој мери помешане, да је тешко поуздано приписати рукопис, рецимо Синајски 8 , једној или другој од њих. Вероватно текст ових рукописа одражава раширену праксу свога времена, као што показују примери који су пред вама.

Према томе следи да у књижевној анализи текстова из XIII века треба тражити библијске алузије у рукописима као што је Синајски 8 , а не претпоставити да су писци слободно цитирали, ако се формулација њихових цитата не подудара са Синајским глагољским, Погодиновим или Болоњским псалтиром. Такође можемо закључити да преписивачи Доментијана нису правили измене у његовим цитатима.

Коначно, сложени међуутицаји раних традиција у XIII веку најочигледније су илустровани Доментијановим поновљеним цитатом из псалма 19:8. Грчки текст $\varepsilon v \alpha \rho \mu \alpha \sigma \imath v$ исправно је преведен у свим редакцијама као на колєсьннцахь. Али то, изгледа, није верзија коју је Доментијан знао. Он пише в ороүжнн, а то је варијанта која се заснива или на каснијој грчкој традицији или на латинском утицају. Оно се повремено јавља у раним рукописима - у Синајском глагољском, Јарославском и неким другим руским рукописима - и укључено је у Норовљев псалтир. Било Доментијан, било неки од његових преписивача, додао је на колєсьннцахь, али је задржао вь ороүжнн на првом месту у цитату. На тај начин он је сачувао рану варијанту коју само понекад налазимо у рукописима Псалтира који

${ }^{19}$ ф. 87, MC 4 (М. 1687) у Руској Државној Библиотеци у Москви. 
су допрли до нас. Доказни материјал ове врсте, када је реч о раној традицији псалтирног текста, од изузетне је вредности, посебно у случају првих десет до двадесет псалама, који су често изгубљени у рукописима. Тај материјал оправдава наду Станојевића и Глумца да ће њихов труд допринети реконструкцији црквенословенског превода Светог писма у оном облику, у коме је био познат Србима у раном средњем веку.

\section{Примери}

Данило et al.

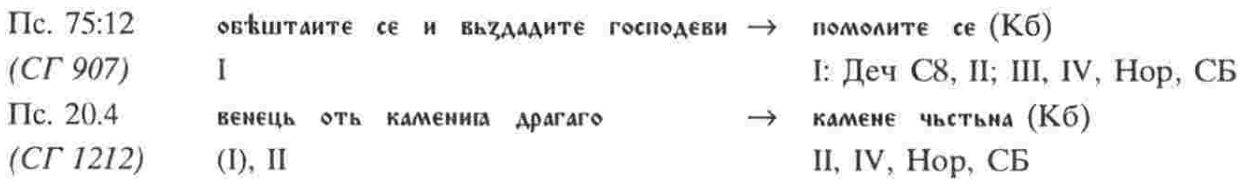

Пр. 21:6 кь тевњ вьzваше и спасли се соүты $\rightarrow$ сынасоше се (Кб)

(СГ 1080) I, II II: Jap, III, IV, Нор, СБ

Пс. 25:8 вьзпювихь красотоу Аомоу твокго $\rightarrow$ вмагольшик (Кб)

(CГ 1104) I, II IIl. IV, Нор, СБ

П. 114:7 пако Господа Аовро тевћ сьтвори $\rightarrow$ вмагодћиствова те (Кб)

(CГ 1334) I, II Hop, СБ (в^aro сьтвори III, IV)

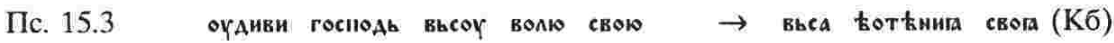

(CT 1261) I, Il, Hop III, IV, CБ

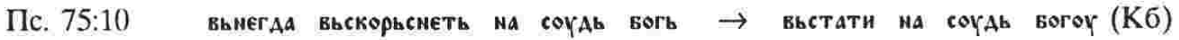

(CГ 1331) I, II, III IV, Hop, СБ

Пс. 85:11 маведи ме ма поүть твои $\rightarrow$ мастави (Кб 899, Ка + Кб 1280)

(СГ 899/7280) I, Ill IV Нор, Сб (направи II)

Пс. 41.1 имиже нравы жедакть (желакть Кб) клень

(СГ 1126) цф. Нор: имьже мравшмь (Імьже овразомъ I: Син, III, IV, CБ)

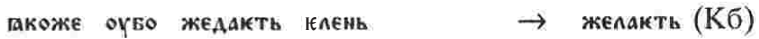

(CT 1192) I, II III, IV, Hop, СБ

П. 39.11 wе потаихь мипости твгеке и истины твокк оть сьвора многа ↔еьньма (Л)

(CГ 1125) II I, III, IV, Hop, СБ

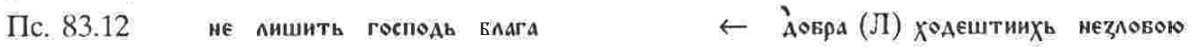

(CГ 1332) III, IV, Hop, (СБ) I, II I, Il, III IV, CБ

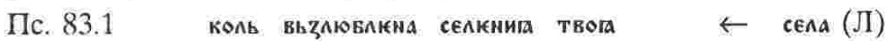

(CГ 1312) СБ I, II, III, IV (Nor: гако

Пс. 54:9 оть малодогишига и воүре

(CГ 1994) III, IV, Нор, СБ (wтrb прьнемаганига Ашж и воүра I, II) 
Повелье

Пс. 25:8 вьзлювихь красоту Аому твокго влагольпик $(1318,1330,1397)$ $(1330-1,1347-8)$

(CГ 1668 etc.) I, II (CГ 1647 etc.) III, IV, Hop

Пс. 132:1 се коль АОвро и коль красьно кеЖЕ (1330) се что довро или что красно Hь кже (1357)

(CГ 1666) I, II

Пс. 101:27 ТыИ же исть кеи (1242)

(CI 1733) III, IV, Hop

(СГ 1579) II: Пљ Бел

тажАє (1288)

и ntта твога ne wekoyathotb

(CГ 1579/91) I: Деч, II, III, IV

(исконьчањжтв сA 1, НОр)

\title{
Записu
}

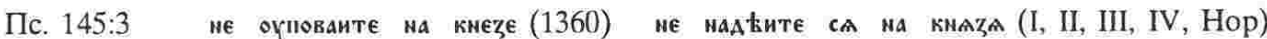
(CI 1836)

\section{Стебан Првовенчани}

\author{
Пс. 19:9 ма Же вистахомь " ирости выхомь \\ (СГ 135) I. II (испракихомь се III. IV Hop)

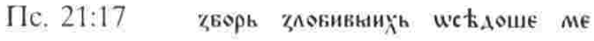 \\ (СГ 138) II (съньмъ I, II: Jap, III, IV, Hор) (пеүкавыниь III, IV (Hор)) \\ Пс. 36:6 извєдєть аки свћть \\ (CT 125) II: Хар Бел1 (пко I. II. III, IV. Hop)
}




\section{Доментијан}

Пс. 132:1 чьто Аовро ипи чьто красьно кеже жити вратии вь коупн

(CT I88) III, IV, Hop се коль Аевро и коль красьно кже жити светымМ вь коүић

(CГ 332) I, II

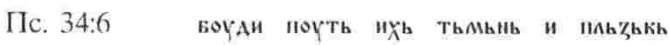

(CT 502) I, III. IV. Hop (c'sвпаzнъ II)

П.. $151: 1$ мьни вбхи вь Брлтии моки

(CT 158) I, II. Hop (manb III, IV)

Пс. 46:9 выцари се вог нады кеыкы

(СГ 284) II, III. IV. Hop (надъ вьсћми жжбъыкы I)

Пс. 39:3 оть рова страстии и оть врьнига тиньна

(ciitp. 83) II: Jap (тимьнна I, II, III, Hop; wт тимьніа гаявины II)

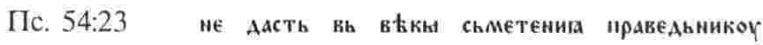

(СГ 188) I: Cצ, II

Пс. 85:14 сьборь крђиькыихь вьзискаше доүше мөке

(СГ 176) I: Гри Деч Су, II (съньмъ I, III. IV, Нор) (Аръжавных IV)

Пт. $46: 8$ поите кмму разоүмино

(CГ 184) I: Гри Деч C8, II: Jap (понте разоүмьно I, II, III, IV, Нор)

Пс. 141:5 и не вt кьто вьzискак доүше мокк

(СГ 226) I: Гри Деч (нћсть въъыскажи I, II: Jap, III, IV, Нор; мє вћ вьзискак II: ПЈь Бел)

Пс. 131:4 и покои көлtномла монма

(СГ 555) І: Гри (кротофома I; акротома I: Деч, С8, III; скранигама II, IV, Hop)

Пс. 19:8 си вь өроүжии и на конихь и на колесьницахь

(СГ 223/506) оржжтух Син, Јар, Нор колесьницахы I, II, III, IV

$\mathrm{I}=$ Синајски глагољски (Син), Погодинов, Болоњски, Григоровичев (Гри), Дечански (Деч), Синајски 8 (С8) Псалтир

II = Синајски (ћирилски) 6, Харвардски (Хар), Пљеваљски (Пљ) Јарославски (Јар Псалтир, Београдски одломци (Бел)

III = Београдски универзитетски, Томичев, Карадимовљев, Минхенски Псалтир

IV = Кипријанов, Геннадијев Псалтир

Нор $=$ Норовљев Псалтир

СБ = Синодална Библија 
C.[atherine] M.[ary] MacRobert

WHAT THE SERBIAN MEDIEVAL WRITER'S PSALTER WAS LIKE?

Summary

The quotations from the Psalter excerpted medieval Serbian sources by Stanojević and Glumac frequently differ in their wording from the parallel passages in such well-known manuscripts as the Sinai, Pogodin, Bologna, Sofia and Bucharest Psalters. Comparison with a wider range of psalter manuscripts of the 13th to 15th century, which reflect various chronological stages in the process of deliberate textual revision, make it possible to distinguish between:

1) authorial quotation from a version of the Psalter in current use at the time of writing;

2) scribal correction of quotations to make them conform to a later standard version of the psalter text;

3) authorial paraphrase of quotation from memory.

Solid evidenc e and sound criteria for these distinctions are essential to the interpretation both of textual history and of authorial method and intention. 